\title{
Teaching NeuroImages: CLOVES Syndrome
}

Meagan Collins, BS, * Eric Krochmalnek, BS, * Sarah Alsubhi, MD, and Myriam Srour, MD, PhD

Neurology ${ }^{\circledR}$ 2021;96:e1487-e1488. doi:10.1212/WNL.0000000000010856

Figure Clinical and Radiologic Findings

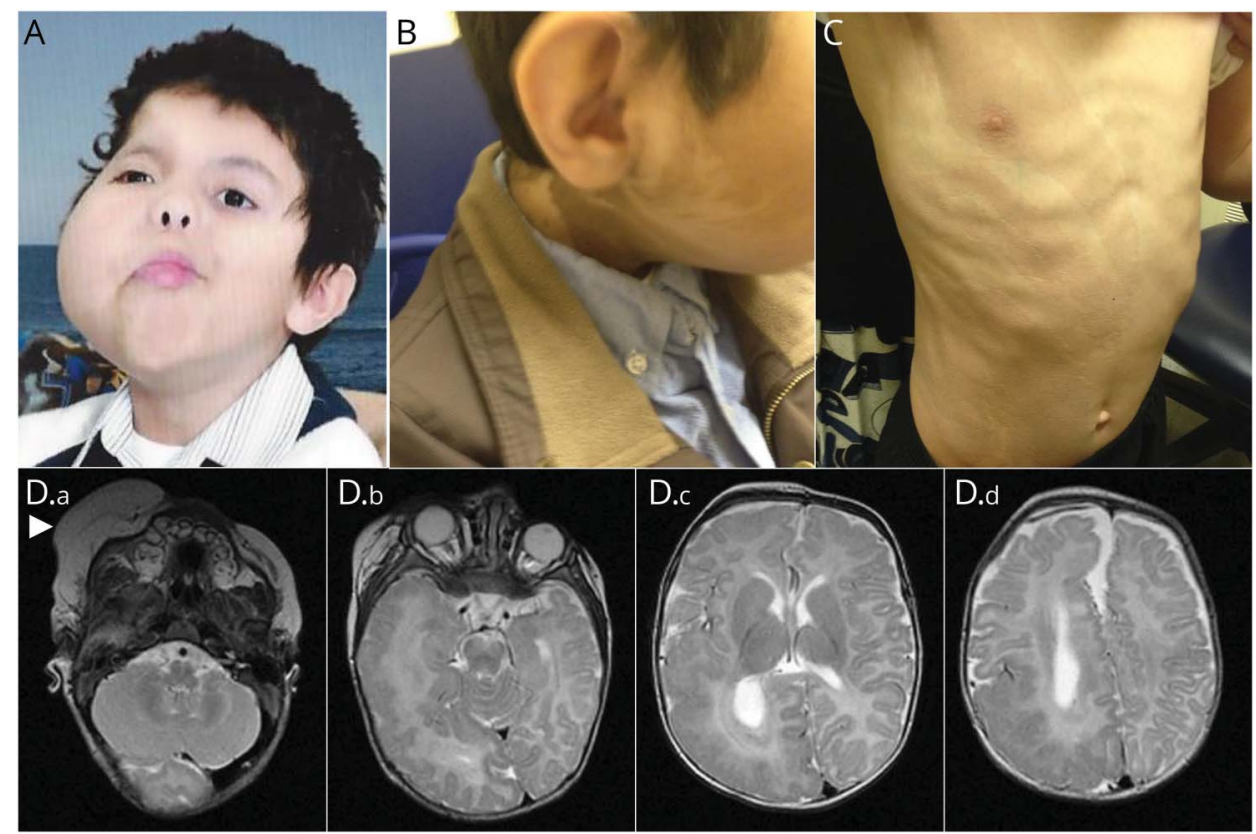

(A) Right hemifacial overgrowth in our patient with CLOVES syndrome. (B) Epidermal nevus on the right face and neck. (C) The epidermal nevus on the trunk, characterized by hyperpigmentation and epidermal thickening, follows Blaschko lines and suggests the presence of an underlying somatic mutation. (D.a-D.d) Axial 1.5T brain MRI at age 2 months reveals right hemimegalencephaly, enlarged right ventricle, and extensive cortical dysplasia in the right temporal, parietal, and occipital lobes. There is blurring of the gray-white border and polymicrogyric appearance of the cortex. Note the lipomatous overgrowth of the right face (arrowhead) (D.a). CLOVES = congenital lipomatous overgrowth with vascular, epidermal, skeletal, and spinal anomalies.

A 17-year-old boy was diagnosed with congenital lipomatous overgrowth with vascular, epidermal, skeletal, and spinal anomalies (CLOVES) syndrome, ${ }^{1}$ mainly affecting his right face, brain, and trunk (MIM\#612918) (figure, A-C). Brain MRI revealed right hemimegalencephaly with extensive temporo-parieto-occipital cortical dysplasia (figure 1, D1-4). He developed neonatal drug-resistant seizures requiring right hemispherectomy at 15 months. He has left hemiparesis and intellectual disability. CLOVES syndrome is a segmental overgrowth syndrome associated with somatic hyperactivating mutations in PIK3CA, belonging to the mammalian target of rapamycin signaling pathway. ${ }^{2}$ Genetic testing on buccal swab revealed a pathogenic somatic missense mutation in PIK3CA (NM_006218.4:c.1624G>A, p.Glu542Lys) at an alternate allele frequency of 4.5\%, which was absent in blood.

\section{Acknowledgment}

The authors thank the patient and the parents for their contribution to this study.

\section{Correspondence}

Dr. Srour

myriam.srour@mcgill.ca

\section{MORE ONLINE}

$\rightarrow$ Teaching slides

links.lww.com/WNL/

B224

From the Child Health and Human Development Program (M.C., E.K., M.S.), Research Institute of the McGill University Health Centre; CHU Sainte Justine Research Center (M.C.), Université de Montréal; and Division of Pediatric Neurology (S.A.S., M.S.), Department of Pediatrics, McGill University, Montreal, Quebec, Canada.

Go to Neurology.org/N for full disclosures. Funding information and disclosures deemed relevant by the authors, if any, are provided at the end of the article. 


\section{Study Funding}

No targeted funding reported.

\section{Disclosure}

The authors report no disclosures relevant to the manuscript. Go to Neurology.org/N for full disclosures.

\section{Appendix Authors}

\begin{tabular}{|c|c|c|}
\hline Name & Location & Contribution \\
\hline $\begin{array}{l}\text { Meagan } \\
\text { Collins, BS }\end{array}$ & $\begin{array}{l}\text { Child Health and Human } \\
\text { Development Program, } \\
\text { Research Institute of the } \\
\text { McGill University Health } \\
\text { Centre, Montreal, } \\
\text { Quebec, Canada } \\
\text { CHU Sainte Justine } \\
\text { Research Center, } \\
\text { Université de Montréal, } \\
\text { Quebec, Canada }\end{array}$ & $\begin{array}{l}\text { Drafting/revising the } \\
\text { manuscript, study } \\
\text { concept or design, } \\
\text { accepts responsibility for } \\
\text { conduct of research and } \\
\text { final approval, acquisition } \\
\text { of data, and study } \\
\text { supervision }\end{array}$ \\
\hline $\begin{array}{l}\text { Eric } \\
\text { Krochmalnek, } \\
\text { BS }\end{array}$ & $\begin{array}{l}\text { Child Health and Human } \\
\text { Development Program, } \\
\text { Research Institute of the } \\
\text { McGill University Health } \\
\text { Centre, Montreal, } \\
\text { Quebec, Canada }\end{array}$ & $\begin{array}{l}\text { Drafting/revising the } \\
\text { manuscript, study } \\
\text { concept or design, } \\
\text { accepts responsibility for } \\
\text { conduct of research and } \\
\text { final approval, acquisition } \\
\text { of data, and study } \\
\text { supervision }\end{array}$ \\
\hline
\end{tabular}

Appendix (continued)

\begin{tabular}{|c|c|c|}
\hline Name & Location & Contribution \\
\hline $\begin{array}{l}\text { Sarah Alsubhi, } \\
\text { MD }\end{array}$ & $\begin{array}{l}\text { Division of Pediatric } \\
\text { Neurology, Department } \\
\text { of Pediatrics, McGill } \\
\text { University, Montreal, QC, } \\
\text { Canada }\end{array}$ & $\begin{array}{l}\text { Drafting/revising the } \\
\text { manuscript, study } \\
\text { concept or design, } \\
\text { accepts responsibility for } \\
\text { conduct of research and } \\
\text { final approval, acquisition } \\
\text { of data, and study } \\
\text { supervision }\end{array}$ \\
\hline $\begin{array}{l}\text { Myriam Srour, } \\
\text { MD, PhD }\end{array}$ & $\begin{array}{l}\text { Child Health and Human } \\
\text { Development Program, } \\
\text { Research Institute of the } \\
\text { McGill University Health } \\
\text { Centre, Montreal, } \\
\text { Quebec, Canada } \\
\text { Division of Pediatric } \\
\text { Neurology, Department } \\
\text { of Pediatrics, McGill } \\
\text { University, Montreal, } \\
\text { Quebec, Canada }\end{array}$ & $\begin{array}{l}\text { Drafting/revising the } \\
\text { manuscript, study } \\
\text { concept or design, } \\
\text { accepts responsibility for } \\
\text { conduct of research and } \\
\text { final approval, acquisition } \\
\text { of data, and study } \\
\text { supervision }\end{array}$ \\
\hline
\end{tabular}

\section{References}

1. Gucev ZS, Tasic V, Jancevska A, et al Congenital lipomatosis overgrowth, vascular malformations, and epidermal nevi (CLOVE) syndrome: CNS malformations and seizures may be a component of this disorder. Am J Med Genet 2008;146A:2688-2690.

2. Kurek KC, Luks VL, Ayturk UM, et al. Somatic mosaic activating mutations in PIK3CA cause CLOVES syndrome. Am J Hum Genet 2012;90:1108-1115. 


\title{
Neurology
}

\author{
Teaching NeuroImages: CLOVES Syndrome \\ Meagan Collins, Eric Krochmalnek, Sarah Alsubhi, et al. \\ Neurology 2021;96;e1487-e1488 Published Online before print December 1, 2020 \\ DOI 10.1212/WNL.0000000000010856
}

This information is current as of December 1, 2020

$\begin{array}{ll}\begin{array}{l}\text { Updated Information \& } \\ \text { Services }\end{array} & \begin{array}{l}\text { including high resolution figures, can be found at: } \\ \text { http://n.neurology.org/content/96/10/e1487.full }\end{array} \\ \text { References } & \begin{array}{l}\text { This article cites } 2 \text { articles, } 0 \text { of which you can access for free at: } \\ \text { http://n.neurology.org/content/96/10/e1487.full\#ref-list-1 }\end{array} \\ \text { This article, along with others on similar topics, appears in the } \\ \text { following collection(s): } \\ \text { Cortical dysplasia } \\ \text { http://n.neurology.org/cgi/collection/cortical_dysplasia } \\ \text { Developmental disorders } \\ \text { http://n.neurology.org/cgi/collection/developmental_disorders } \\ \text { Other neurocutaneous disorders } \\ \text { http://n.neurology.org/cgi/collection/other_neurocutaneous_disorders } \\ \text { Information about reproducing this article in parts (figures,tables) or in } \\ \text { its entirety can be found online at: } \\ \text { http://www.neurology.org/about/about_the_journal\#permissions } \\ \text { Information about ordering reprints can be found online: } \\ \text { http://n.neurology.org/subscribers/advertise }\end{array}$

Neurology ${ }^{\circledR}$ is the official journal of the American Academy of Neurology. Published continuously since 1951, it is now a weekly with 48 issues per year. Copyright @ 2020 American Academy of Neurology. All rights reserved. Print ISSN: 0028-3878. Online ISSN: 1526-632X.

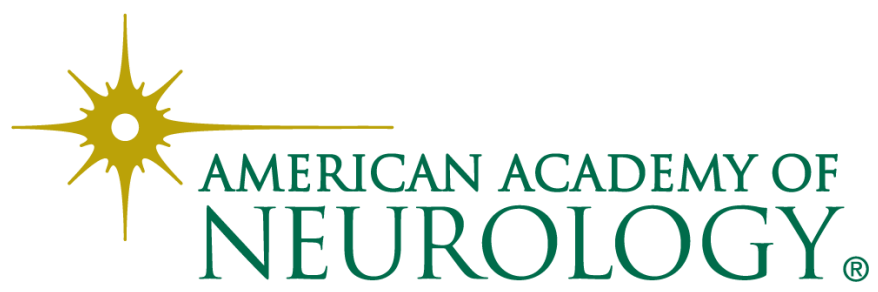

